Harvard Historical Studies • 168

Published under the auspices of the Department of History

from the income of the

Paul Revere Frothingham Bequest

Robert Louis Stroock Fund

Henry Warren Torrey Fund 



\title{
Revolutionary Commerce
}

\section{GLOBALIZATION AND THE}

FRENCH MONARCHY

\author{
Paul Cheney
}

Harvard University Press

Cambridge, Massachusetts • London, England 
Copyright (C) 2010 by the President and Fellows of Harvard College

All rights reserved

Printed in the United States of America

Library of Congress Cataloging-in-Publication Data

Cheney, Paul Burton.

Revolutionary commerce: globalization and the French monarchy / Paul Cheney.

p. cm. - (Harvard historical studies; 168)

Includes bibliographical references and index.

ISBN 978-0-674-04726-6 (alk. paper)

1. France-Commerce-History-18th century. 2. France-Economic policy-18th

century. 3. France-Economic conditions-18th century. 4. Economics-FranceHistory-18th century. I. Title.

HF3555.C54 2010

$381.0944-\mathrm{dc} 22$

2009034950 
To fessie 
